International Research Journal of Management, IT \& Social Sciences
Available online at https://sloap.org/journals/index.php/irjmis/
Vol. 6 No. 5, September 2019, pages: 60 64
ISSN: 2395-7492
https://doi.org/10.21744/irjmis.v6n5.698

\title{
Effect of Consideration Leadership Style on Budget Participation Relationship and Managerial Performance
}

\begin{tabular}{|c|c|}
\hline & $\begin{array}{r}\text { Made Ika Klaorina } \\
\text { Herkulanus Bambang Suprasto }^{\mathrm{b}}\end{array}$ \\
\hline Article history: & Abstract \\
\hline $\begin{array}{l}\text { Received: } 27 \text { March } 2019 \\
\text { Accepted: } 31 \text { May } 2019 \\
\text { Published: } 20 \text { August } 2019\end{array}$ & $\begin{array}{l}\text { The research aims to empirically prove the influence of consideration } \\
\text { leadership style on the relationship of budgeting participation to managerial } \\
\text { performance. Contingency Theory is used as a theoretical foundation in this } \\
\text { study. The study population was the middle-level manager (section head) at } \\
\text { the Rural Credit Bank (BPR) in Badung Regency. The method of determining } \\
\text { the sample is based on the slovin formula, the sample selection technique uses }\end{array}$ \\
\hline $\begin{array}{l}\text { Keywords: } \\
\text { budgeting; } \\
\text { leadership style; } \\
\text { managerial; } \\
\text { participation; }\end{array}$ & $\begin{array}{l}\text { a probability sampling technique that is taken proportionally using simple } \\
\text { random sampling so that } 135 \text { respondents are obtained. Data were analyzed } \\
\text { with Moderated Regression Analysis (MRA). The results of the analysis show } \\
\text { that budgetary participation has a positive effect on managerial performance } \\
\text { and leadership style consideration reinforces the relationship between } \\
\text { budgeting participation and managerial performance. }\end{array}$ \\
\hline
\end{tabular}

2395-7492@ Copyright 2019. The Author. This is an open-access article under the CC BY-SA license (https://creativecommons.org/licenses/by-sa/4.0/) All rights reserved.

\section{Author correspondence:}

Made Ika Klaorina,

Faculty of Economic and Business Udayana University, Denpasar, Indonesia.

Email address: ikaklaorina@gmail.com

\section{Introduction}

The poor human resource factor in banking will cause a decline in the quality of banking services which has an impact on decreasing competitiveness so that the human performance involved in it is important to be optimized. The role of managers, in this case, is needed because in producing performance, in addition to maximizing its potential, the manager also directs the talents, abilities, and efforts of several other people who are in their area of authority. Trissandy (2012), states that managerial performance is the manager's performance in managerial activities which include: planning, investigating, coordinating, evaluating, supervising, staffing, negotiating, and representing or representing. Managerial performance is a measure of how effectively and efficiently managers have worked to achieve organizational goals.

Bank Perkreditan Rakyat is demanded to carry out management control as a means to determine the planning, coordination, and evaluation of the company's operations so as to a better direction, to carry out these tasks requires

a Udayana University, Denpasar, Indonesia

${ }^{\mathrm{b}}$ Udayana University, Denpasar, Indonesia 
management's ability to manage and allocate the company's economic resources effectively and efficiently. One of the tools that can be used in the planning and control process is the budget (Aristianto, 2015; Prihantari \& Astika, 2019). The budget is one of the planning and control tools so that managers can carry out organizational activities more effectively and efficiently (Rosidi, 2000; Sari \& Dwirandra, 2019). The budget is a statement of the estimated performance to be achieved over a certain period of time expressed in financial measures. The success of the budget will be determined by a process or method used to make a budget, this process is called budgeting.

Budgeting with an authorization approach, where the budget has been set by superiors can result in the performance of executors to be ineffective because superiors do not know the potential and obstacles owned by managers as executors, so the budget made will be difficult to realize because the targets provided with resources are not commensurate. The budget in its preparation must consider the company's goals and employee goals. The consistency of these two goals is called goal congruence. One approach that encourages goal congruence is avoiding budgeting authorization and using the participatory budgeting approach. Budgeting is based on a participatory approach not only to align the two aspects but also so that the budget can be carried out as expected without changing the company's initial objectives. Manager's participation in determining the budget has a positive influence on managerial performance because the budget compiled with the participation of subordinates will produce an effective exchange of information (Susanta, 2004; Martini et al., 2018). The involvement of managers in budgeting will also enable them to communicate or disclose some personal information that can be considered in budgeting. Subordinate participation in budgeting can provide an opportunity to enter local information (Suprasto, 2006; Sukayana \& Putri, 2019). Budgeting participation causes alignment between the objectives of the manager and the company which results in improved manager performance.

The right leadership style in the Rural Credit Bank in Badung Regency will deliver it towards improved performance. At present, the world of banking competes to be the best in the midst of competition between banks. According to Coster \& Fertakis (1968) in Sumarno (2005), the right leadership style is a leadership style that is directed at openness and is more humanistic, called the consideration leadership style. With good support and communication with leaders who adopt the consideration leadership style, it will be able to arouse the enthusiasm of managers involved in budgeting to work better, in order to obtain results in the form of managerial performance improvement. This is the reason for choosing the consideration leadership style variable as a variable that moderates the relationship between budgeting participation and managerial performance.

\section{Literature Review and Hypothesis}

Leaders do not fully act rationally in decision making because of the limited ability to process the information obtained. Leaders need the help of subordinates to process information in order to make accurate planning (Asriningati, 2006). Budgeting participation in budgeting where subordinates are given the opportunity to be involved and have influence in the budget preparation process. The opportunity to be involved in budgeting is believed to improve the performance of managers. Managers, as budget implementers, have more detailed information about opportunities and obstacles that occur in the field. Managers involved in budgeting will feel the budget as a collective agreement. The manager considers the purpose of the budget is also the goal. The manager does not hesitate to provide all the information he has that can be taken into consideration in budgeting. Budgeting participation has an impact on improving the performance of managers and indirectly will lead the company in a better direction.

Good collaboration between individuals who coordinate, direct, and carry out organizational activities must be well established. Leaders can often influence performance, job satisfaction, security and employee morale in an organization. Sutarto (2001), states that leadership is a major problem in organizational management, organizational growth, whether or not someone works in an organization, and whether or not the goals of the organization are achieved, partly determined by the appropriateness of leadership applied by the organization concerned. The right leadership style in an organization will deliver the organization to performance improvement. Leadership style consideration is a leadership style that is oriented to employees. This leadership style prefers social aspects, namely how the relationship between superiors and subordinates must be made so that organizational goals can be achieved. Leadership style consideration emphasizes the close relationship between subordinates and superiors, the existence of the mutual trust, and respect for subordinate ideas are believed to improve the performance of managers involved in budgeting participation.

Klaorina, M. I., \& Suprasto, H. B. (2019). Effect of consideration leadership style on budget participation relationship and managerial performance. International Research Journal of Management, IT and Social Sciences, 6(5), 60-64. https://doi.org/10.21744/irjmis.v6n5.698 


\section{Hypothesis}

H1 : Budgetary participation has a positive effect on managerial performance.

H2 : Consideration leadership style strengthens the relationship between budgetary participation and managerial performance.

\section{Materials and Methods}

The population in this study is the manager of the Rural Credit Bank in Badung Regency. The research data used are primary data and secondary data. Primary data is data obtained directly from the original source both by questionnaire and by direct interview. The data used in this study are primary data obtained based on the results of respondents' answers in the questionnaire which is a list of structured questions addressed to mid-level managers (section heads) involved in budgeting and who have held office for at least one year. Secondary data in this study is data regarding the name, address, and a number of rural banks. The method of taking samples is to use the Slovin formula with a degree of error of $5 \%$. The analysis technique used to analyze multiple linear regression analysis data.

\section{Results and Discussions}

\subsection{Multiple Linear Regression Analysis}

Multiple linear regression analysis was used to determine the effect of consideration leadership style variables (X2) and affective organization commissions (X3) on the relationship between budgeting participation variables (X1) on managerial performance (Y). The results of the regression test are shown in Table 1.

Table 1

Regression Test Results

\begin{tabular}{|c|c|c|c|c|c|}
\hline \multirow[t]{2}{*}{ Model } & \multicolumn{2}{|c|}{$\begin{array}{c}\text { Unstandardized } \\
\text { Coefficients }\end{array}$} & \multirow{2}{*}{$\begin{array}{l}\begin{array}{c}\text { Standardized } \\
\text { Coefficients }\end{array} \\
\text { Beta }\end{array}$} & \multirow[t]{2}{*}{$\mathrm{t}$} & \multirow[t]{2}{*}{ Sig. } \\
\hline & $\mathrm{B}$ & Std. Error & & & \\
\hline $\begin{array}{ll}1 & \text { (Constant) }\end{array}$ & 1,195 & 3,850 & & 0,310 & 0,757 \\
\hline $\mathrm{X}_{1}$ & 0,746 & 0,297 & 0,489 & 2,510 & 0,013 \\
\hline $\mathrm{X}_{2}$ & $-0,015$ & 0,110 & $-0,029$ & $-0,137$ & 0,892 \\
\hline Adjusted R Square & & & 0,722 & & \\
\hline F-test & & & 63,955 & & 0,000 \\
\hline
\end{tabular}

Primary Data, 2019

\subsection{Determination Coefficient Test}

Based on Table 1, the value of Adjusted R Square 0.722 shows that $72.2 \%$ of the dependent variable can be explained by the independent variable. The remaining $27.8 \%$ is explained by other variables not included in the model.

F test

Table 1 shows the calculated $F$ value of 63.955 with a significance of 0.000 , small from the established real level of 0.05 . It can be concluded that the regression model of this study is feasible to use.

3.3 The Effect of Budgeting Participation on Managerial Performance of Rural Credit Banks (BPR) in Badung Regency

Based on the results of statistical tests on the first hypothesis obtained a positive coefficient value of 0.746 with a $\mathrm{p}$-value of $0.013 \leq 0.05$, meaning that if other independent variables value is fixed and budgeting participation (X1) has increased by one unit, then the managerial performance $(\mathrm{Y})$ will increase by 0.746 units. The p-value test result of 
$0.013 \leq 0.05$ shows that $\mathrm{H} 1$ is accepted, which means budgetary participation has a positive effect on managerial performance. These results indicate that the greater the participation of managers involved in the budgeting process, the higher the performance achievement of the managers themselves. The results of testing the first hypothesis have the same results with research conducted by Usman et al., (2016), who examined the effect of budgetary participation on managerial performance and found that there was a positive and significant relationship between budgeting participation and managerial performance. The same results as a study conducted by Anggarini \& Sujana (2016), shows that budgetary participation has a positive effect on managerial performance, and research by Dewi (2017) and Apriansyah et al., (2014), found that high participation in budgeting can improve managerial performance. Different results were found in a study conducted by Medhayanthi \& Suardana (2015), researchers conducting research at the Denpasar Rural Bank (BPR) found that budgetary participation had a negative relationship with managerial performance. This is because the director and head of the department have a low initiative to initiate discussions in the preparation of the budget so that the impact on managerial performance is declining. Different results found by Locke et al., (1968), show that there is a negative influence between budgeting participation on managerial performance.

\subsection{The Effect of Leadership Style Consideration in Moderating the Relationship between Budgeting Participation to the Managerial Performance of Rural Credit Banks (BPR) in Badung Regency}

Based on the results of statistical tests on the second hypothesis obtained a positive coefficient of 0.015 with a pvalue of $0.021 \leq 0.05$, meaning that if the other independent variables value is fixed and the leadership style consideration variable (X2) has increased by one unit, then the interaction between budgeting participation variables (X1) and managerial performance (Y) will increase by 0.021 units. These results indicate that $\mathrm{H} 2$ is accepted which means that consideration leadership style is able to strengthen the relationship between budgeting participation and managerial performance. These results indicate that in the budget preparation process which involves the manager's participation in budgeting will have a greater influence if consideration leadership styles are applied.

The results of testing the second hypothesis have the same results with research conducted by Sumarno (2005), examining the influence of leadership style with the relationship between budgetary participation and managerial performance and found that leadership style has a positive effect on the relationship between budgeting participation and managerial performance. Different results found by Maharani (2010) \& Romario et al., (2019), indicate that budgetary participation has a positive and significant effect on managerial performance but leadership style does not moderate the relationship between budgeting participation and managerial performance.

\section{Conclusion}

Budgeting participation has a positive effect on managerial performance and second, consideration leadership style strengthens the relationship between budgetary participation and managerial performance.

Conflict of interest statement and funding sources

The authors declared they have no competing interest.

Statement of authorship

The authors have a responsibility for the conception and design of the study. The authors have approved the final article.

\section{Acknowledgments}

The authors would like to thank the editor of IRJMIS for their valuable time, support, and advice in completing the present paper.

Klaorina, M. I., \& Suprasto, H. B. (2019). Effect of consideration leadership style on budget participation relationship and managerial performance. International Research Journal of Management, IT and Social Sciences, 6(5), 60-64. https://doi.org/10.21744/irjmis.v6n5.698 


\section{References}

Anggarini, N. N. D., \& Sujana, I. K. (2016). Pengaruh partisipasi anggaran pada kinerja manajerial PT. BPD Bali cabang Tabanan: motivasi sebagai variabel pemoderasi. E-Jurnal Akuntansi, 66-78.

Apriansyah, Y., Prabawa, S. A., \& Kamaludin, K. (2014). Analisis Pengaruh Kurs (Usd/Idr), Suku Bunga Sertifikat Bank Indonesia (Sbi), Inflasi Dan Indek Nikkei 225 Terhadap Indeks Harga Saham Gabungan (Ihsg) Di Bursa Efek Indonesia (Bei) Periode Januari 2004-Agustus 2013 (Doctoral dissertation, Universitas Bengkulu).

Aristianto, W. Y. (2015). Prosedur Penyelesaian Pemberitahuan Impor Barang (PIB) dengan Menggunakan Media Berbasis Web di Kantor Pengawasan Bea dan Cukai Tipe Madya Pabean B Yogyakarta (Doctoral dissertation, Universitas Islam Indonesia).

Asriningati, R., \& Safitri, D. K. (2015). Risiko Diabetic Foot Ulcer (DFU) Pada Pasien di Wilayah Kerja Puskesmas Kedungmundu Semarang (Doctoral dissertation, Diponegoro).

De Coster, T. D., \& Fertakis, P. J. 1968. Budget-induced pressure and its relationship to supervisory behavior. Journal of Accounting research (Autumn), 237-246.

Locke, E. A., Bryan, J. F., \& Kendall, L. M. (1968). Goals and intentions as mediators of the effects of monetary incentives on behavior. Journal of Applied Psychology, 52(2), 104. https://psycnet.apa.org/doi/10.1037/h0025492

Maharani, K. (2010). Analisis Perbandingan Kinerja Keuangan Perbankan Syariah Dengan Perbankan Konvensional Dengan Menggunakan Rasio Keuangan.

Martini, L. K. B., Suardana, I. B. R., \& Astawa, I. N. D. (2018). Dimension Effect of Tangibles, Reliability, Responsiveness, Assurance, Empathy, Leadership towards Employee Satisfaction. International Research Journal of Management, IT and Social Sciences, 5(2), 210-215.

Prihantari, G. A. P. E. D., \& Astika, I. B. P. (2019). Effect of role overload, budget participation, environmental uncertainty, organizational culture, competence, and compensation on employee performance. International Research Journal of Management, IT and Social Sciences, 6(4), 197-206. https://doi.org/10.21744/irjmis.v6n4.682

Romario, F. D., Putri, I. G. A. M. A. D., Badera, I. D. N., \& Putra, I. N. W. A. (2019). Effect of budget participation towards regional government managerial performance. International Research Journal of Management, IT and Social Sciences, 6(3), 101-107. https://doi.org/10.21744/irjmis.v6n3.638

Rosidi, A. (2000). Manajemen Keuangan. Materi Kuliah Program Magister, STIE-ISM. Jakarta.

Sari, I. G. A. D. I., \& Dwirandra, A. (2019). The ability of organization commitment and moderate worked motivation by the effect of budget goal clarity in budgetary inaccuracy. International Research Journal of Management, IT and Social Sciences, 6(3), 11-17. https://doi.org/10.21744/irjmis.v6n3.622

Sukayana, G. A., \& Putri, I. A. D. (2019). Tri hita karana culture and organizational commitments moderate: effect of participation on budgetary slack. International Research Journal of Management, IT and Social Sciences, 6(4), 180-188. https://doi.org/10.21744/irjmis.v6n4.676

Sumarno, J. (2005). Pengaruh Komitmen Organisasi dan Gaya Kepemimpinan Terhadap Hubungan Antara Partisipasi Anggaran Dengan Kinerja Manajerial. Jurnal SNA, 8, 586-616.

Suprasto, B. H.(2006). Peluang dan Tantangan Implementasi Anggaran Berbasis Kinerja. Buletin Studi Ekonomi, 11(3), 270-281.

Susanta, S. (2004). Job Relevant Information dan Ketidakpastian Lingkungan Dalam Hubungan Partisipasi Penyusunan Anggaran dan Kinerja Manajerial. Simposium Nasional Akuntansi VII.

Sutarto, A. P., Wahab, M. N. A., \& Zin, N. M. (2010). Heart Rate Variability (HRV) biofeedback: A new training approach for operator's performance enhancement. Journal of industrial engineering and management, 3(1), 176198.

Trissandy, D. K. (2012). Pengaruh Pengendalian Akutansi, Pengendalian Perilaku, Dan Pengendalian Personal Terhadap Kinerja Manajerial (Doctoral dissertation, Sekolah Tinggi Ilmu Ekonomi Musi).

Usman, E., \& Usman, A. (2016). Leadership Styles in Budgeting Participation to Support Managerial Performance. International Journal of Organizational Innovation (Online), 8(4), 251.

Yanti, P. M., \& Suardana, K. A. Pengaruh partisipasi anggaran terhadap kinerja manajerial dengan self efficacy, desentralisasi, dan budaya organisasi sebagai variabel pemoderasi. E-Jurnal Akuntansi, 155-170. 